\title{
Establishment of hematological parameters in boas (boa constrictor) in the centro de atencion $y$ valoracion de fauna silvestre del valle de aburra (Cav
} amva)

\begin{abstract}
In the CAV-AMVA (Center for attention and Evaluation) of wildlife, located in Barbosa Antioquia, belonging to the Area Metropolitana del Valle de Aburra, were taken the data of hematological values of 92 Boa constrictor, which enter to the center from July of 2015 to July of 2016. Once the data were taken, a retrospective descriptive analysis was performed. The reference values for hematology and blood chemistry of Boa constrictor were taken into account: total erythrocyte count (Millions $/ \mathrm{mm} 3$ ), total white blood cell count (Thousands/Mm3), differential count of leukocytes "Heterophils (\%), lymphocytes (\%), eosinófilo (\%), basófilos (\%) and monocitos (\%), trombocytes $(\mathrm{G} / \mathrm{dl})$, albumin $(\mathrm{g} / \mathrm{dl})$, glucose $(\mathrm{mg} / \mathrm{dl})$, hemoglobin $(\mathrm{g} / \mathrm{dl})$, mean corpuscular volume, mean corpuscular hemoglobin/Dl), aspartate aminotransferase (AST) (U/L), Alanine aminotransferase (ALT) (U/L), Urea $(\mathrm{mg} / \mathrm{dl})$, Phosphorus $(\mathrm{mg} / \mathrm{dl})$, Calcium $(\mathrm{mg} /$ $\mathrm{dl})$ and Albumin $(\mathrm{g} / \mathrm{dl})$. For the statistical analysis, the animals were divided into 4 groups, considering sex and age: adult females $(\mathrm{AF}) \mathrm{n}=18$, young females $(\mathrm{JF}) \mathrm{n}=$ 10; Adult males (AM) 52; Young males (JM) $n=12$. The purpose of the analysis was to evaluate whether there were significant differences between males and females by age groups in each of the variables. One-way ANOVA analysis showed the following results: Hematocrit $(\mathrm{Hto} \%)(\mathrm{P}$ value $=0.150)$, total $\mathrm{RBC}$ count $(\mathrm{RTGR}$ Millions $/ \mathrm{mm} 3)$ ( $\mathrm{P}$ value $=0.335$ ) showed no statistically significant differences between the different groups however Hemoglobin $(\mathrm{Hb} \mathrm{gr} / \mathrm{dL})(\mathrm{P}$ value $=0,057)$ could show a variation between the group of Adult males with the other groups. The variable Heterophils $(\%)(\mathrm{P}$ valor $=0,002)$ showed statistically significant differences between the group of Adult Females with Young females ( $\mathrm{P}$ value $=0.006$ ) and adult females with young males $(\mathrm{P}$ valor $=0,031)$ however there was not differences between de other groups. It was determined in this study that there are no significant differences depending on the variable sex. However, in terms of age, there are significant differences in the parameters of Heterophils and lymphocytes
\end{abstract}

Keywords: wildlife, snakes, hematological parameters, sample of blood, clinical examination, laboratory analysis
Volume 3 Issue 2 - 2018

\author{
Juan Camilo Fonseca Sarmiento MVZ,' \\ Gloria Helena Jaramillo,' Diber Marcela \\ Ramirez, ${ }^{2}$ Javier Eduardo Nieto Pico MVZ ${ }^{2}$ \\ 'School of veterinary and zootechny, Universidad Cooperativa \\ de Colombia UCC, Colombia \\ ${ }^{2}$ Centro de Atencion y Valoracion de Fauna Silvestre del Area \\ Metropolitana del Valle de Aburra (cav amva), Colombia
}

\section{Correspondence: Juan Camilo Fonseca MVZ, School of veterinary and zootechny of Cooperativa, University of Colombia, 27 a Street-4I-5I Bucaramanga-Santander, Colombia,Tel 31532240 21, Email kmus2893@hotmail.com}

Received: March 23, 2018 | Published: April 12, 2018
Abbreviations: AST, aspartate aminotransferase; ALT, alanine aminotransferase.

\section{Introduction}

Laboratory analyses often complements the clinical examination of the patient veterinarian. Physiological variables yield objective information in the process of diagnosis, treatment guidance and formulation of prognosis. Abnormal laboratory tests and measurements are defined clinically as values that are not within the limits of the reference ranges, these ranges are obtained by sampling a representative sample of a population. One of the most common problems is to decide if a value that is slightly outside the reference range is indicative of disease or physiological variation, however it is possible to solve it using ranges of references more precise, specific for the age, species, location, management practices, reproductive status, power and laboratory methodology. ${ }^{1}$ The hematological study in reptiles is a little explored field while there is the necessary methodology, and recognizes that blood is responsible for important functions such as the immune response, transportation of nutrients, gases, and metabolic wastes to be disposed of through the liver, kidney, among others. ${ }^{2}$

The interpretation of hematological values is relatively similar to that of the mammals, the normality of the different parameters analyzed intervals are generally wider and are subject to important variations like environmental and management conditions that vary according to the place, and physiological parameters of the animal, such as nutritional status, sex or age, because of this, the values of hematological reference for Boa constrictor published in different parts of the world cannot be taken lightly so it is important to count on hematological values of each place which allows making a more reliable medical appraisal, allowing to improve and expedite the diagnosis and treatment of boidae entering the CAV.

\section{Materials and methods}

\section{Study area}

This work was conducted in the Centro de Atencion y Valoracion de fauna silvestre (center of attention and evaluation of wild fauna) 
belonging to the Area Metropolitana del Valle de Aburra (AMVA) located 23 kilometers from the city of Medellin, in the municipality of Barbosa Antioquia, which is located in area of humid forest, a height above the level of the sea between 1,300 and 1,500 metres an average temperature of $22^{\circ} \mathrm{c}$ and annual rainfall of $2,000 \mathrm{~mm}$.

\section{Population}

Hematological values were analyzed for this study and serum chemistry of 92 species Boa constrictor snakes, for the Organization of the data two variables; were taken into account one of them, sex included 64 males and 28 females, the second variable was the age for this, we evaluated 70 adult boas and 22 youth boas. Snakes of the study entered the CAV of the Area Metropolitana del Valle de Aburra on covered periods between July 2015 and July of the year 2016, all of them coming from the rescue of wildlife traffic made by the environmental police and voluntary deliveries made by the community. Sampling of blood from boas's study was carried out through Cardiocentesis with a 23 gauge needle and drew approximately 0.5 $\mathrm{ml}$ of blood using heparinized microhematocrit capillary tubes. These samples were analyzed immediately to the lab of the CAV

\section{Data analysis}

For all subjects of this study were recorded and analyzed the following variables (Table 1):

a. Sex (male-female) and age (adults-youth)

b. Volume and concentration of the total count of red blood cells (million/mm3), count total of leukocytes (thousands $/ \mathrm{mm} 3$ ), hematocrit $(\%)$, hemoglobin $(\mathrm{g} / \mathrm{dl})$, mean corpuscular volume (MCV) (fl), mean corpuscular hemoglobin (MCH) (pg),

Table $\mathbf{2}$ Values of the Hemoleucogram of the female adult and juvenile group concentration mean corpuscular hemoglobin $(\mathrm{MCHC})(\mathrm{g} / \mathrm{dl})$,

c. Differential count of leukocytes "Heterophile (\%), lymphocytes $(\%)$, Eosinophilic (\%), basophils (\%) and monocytes (\%) and thrombocytes (\%)", Azurophilic (\%)

d. Total protein $(\mathrm{g} / \mathrm{dl})$, albumin $(\mathrm{g} / \mathrm{dl})$, glucose $(\mathrm{mg} / \mathrm{dl})$, aspartate aminotransferase (AST) $(\mathrm{u} / \mathrm{l})$, alanine aminotransferase (ALT) $(\mathrm{u} / \mathrm{l})$, Urea $(\mathrm{mg} / \mathrm{dl}),(\mathrm{mg} / \mathrm{dl})$ uric acid, phosphorus $(\mathrm{mg} / \mathrm{dl})$, calcium $(\mathrm{mg} / \mathrm{dl})$ and albumin $(\mathrm{g} / \mathrm{dl})$

Table I Grouping of individuals by groups

\begin{tabular}{ll}
\hline Group & N \\
\hline Adult Females (A-F) & 18 \\
Youth Females (Y-F) & 10 \\
Adult Males (A-M) & 52 \\
Young Males (Y-M) & 12 \\
\hline
\end{tabular}

For the statistical analysis one- way ANOVA, was taking the sex and age as factors. The level of significance testing was $P$ value 0.05 . We used the resources of Excel spreadsheets (Microsoft Office) and Sigma Stat program v. 3.5 for the statistical analysis

\section{Results}

Hemoglobin $(\mathrm{g} / \mathrm{dl})$ with average value for the Group of adult females of $7,12 \mathrm{~g} / \mathrm{dL} \pm 2.217$ juvenile females, $43 \mathrm{~g} / \mathrm{dL} \pm 0.98$, for male adult $8,12 \mathrm{~g} / \mathrm{dL} \pm 1.41$ and male youth $7.74 \mathrm{~g} / \mathrm{dL} \pm 0.87$ with a $\mathrm{P}-$ value of 0,057 , it would indicate that there could be differences between different groups, as shown in Figure 1, the average values tend to be higher in the Group of males than of females (Table 2-5).

\begin{tabular}{|c|c|c|c|c|c|c|c|}
\hline \multirow[b]{2}{*}{ Parameters } & \multirow[b]{2}{*}{ Unit } & \multicolumn{3}{|c|}{ Adult Females } & \multicolumn{3}{|c|}{ Juvenile Females } \\
\hline & & Average & SD & Rank & Average & SD & Rank \\
\hline Hematocrit & $\%$ & 21,7 & 4,23 & $15-26$ & 23,3 & 2,26 & $20-27$ \\
\hline Hemoglobin & $\mathrm{g} / \mathrm{dL}$ & 7,12 & 2,21 & $3,1-9,2$ & 7,43 & 0,98 & $6-8,8$ \\
\hline Red Blood Cells & $\left(10^{\wedge} \mid 2 / 1\right)$ & 0,64 & 0.22 & $0,2-1$ & 0,75 & 0,6 & $0,4-1$ \\
\hline Mcv & $\mathrm{FI}$ & 341 & 86,9 & $2 \mid 2,7-456, I$ & 327,4 & 111,9 & $237-627$ \\
\hline Mch & $\mathrm{Pg}$ & 116,8 & 28 & $81,8-175,3$ & 117,4 & 1,5 & $75-206,2$ \\
\hline Mchc & $\mathrm{g} / \mathrm{dL}$ & 32,82 & 4,8 & $18-38,3$ & 32,8 & 2,5 & $30-37,1$ \\
\hline White Blood Cells & $\left(10^{\wedge} 9 / 1\right)$ & 10,6 & 6 & $3,9-19,8$ & 8 & 3,5 & $2,8-13,2$ \\
\hline Heterophile & $\%$ & 25,1 & 9 & Oct-4I & 13,2 & 7,2 & $6-30$ \\
\hline Heterophile absolute & $\left(10^{\wedge} 9 / /\right)$ & 2,6 & I,7 & $0.3-6.6$ & I & 0,5 & $0.1-2,1$ \\
\hline Eosinophils & $\%$ & $\mathrm{I}, 5$ & $\mathrm{I}, 8$ & $0-6$ & $\mathrm{I}, 5$ & $\mathrm{I}, 7$ & $0-4$ \\
\hline Eosinophils Absolute & $\left(10^{\wedge} 9 / 1\right)$ & 0,1 & 0,2 & $0-1,1$ & 0,13 & 0,14 & $0-0,33$ \\
\hline Lymphocytes & $\%$ & 36 & 17,3 & $6-67$ & 59,5 & 13,8 & $38-80$ \\
\hline Lymphocytes Absolute & $\left(10^{\wedge} 9 / 1\right)$ & 3,6 & 2,6 & $0,7-9,5$ & 4,9 & 2,7 & $|-|, 5$ \\
\hline Monocytes & $\%$ & 0,9 & 1,6 & $0-6$ & $\mathrm{I}, 4$ & $\mathrm{I}, 7$ & $0-5$ \\
\hline Monocytes Absolute & $\left(10^{\wedge} 9 / 1\right)$ & 0,12 & 0,2 & $0,04-0,3$ & 0,1 & 0,1 & $0,07-0,6$ \\
\hline Azurophils & $\%$ & 32,8 & 15,5 & ||$-6 \mid$ & 20,2 & 7,6 & $6-32$ \\
\hline Azurophils Absolute & $\left(10^{\wedge} 9 / 1\right)$ & 3,5 & 2,7 & $0,6-10$ & $\mathrm{I}, 4$ & 0,7 & $0,7-3$ \\
\hline Basóphils & $\%$ & 2,6 & 3 & $0-13$ & 4,2 & 5,2 & $0-18$ \\
\hline Basóphils Absolute & $\left(10^{\wedge} 9 / /\right)$ & 0,26 & 0,27 & $0.07-0,7$ & 0,3 & 0,5 & $0-0,7$ \\
\hline Thrombocytes & $\left(10^{\wedge} 9 / 1\right)$ & 15,3 & 6,5 & $12,2-24,7$ & 8,8 & 6,4 & $2,3-19.2$ \\
\hline
\end{tabular}


Table 3 Values of blood chemistry of the female adult and juvenile groups

\begin{tabular}{llllllll}
\hline & & \multicolumn{5}{c}{ Adult Females } & \multicolumn{5}{c}{ Juvenile Females } \\
\cline { 3 - 8 } Parameters & Unit & Average & SD & Range & Average & SD & Range \\
\hline Glucose & $\mathrm{mg} / \mathrm{dL}$ & 47.9 & 26.6 & $12.8-103.9$ & 58.1 & 19.5 & 3088.9 \\
Proteins & $\mathrm{g} / \mathrm{dL}$ & 5.9 & 1.46 & $3.3-8.49$ & 5.67 & 0.96 & $4.9-7.1$ \\
Urea & $\mathrm{mg} / \mathrm{dL}$ & 5.17 & 3.7 & $0.6-15.3$ & 3.6 & 3 & $0.8-8.1$ \\
Uric Acid & $\mathrm{mg} / \mathrm{dL}$ & 6.24 & 3.31 & $0.92-14.1$ & 4.01 & 4.07 & $2.68-13.8$ \\
AST & $\mathrm{U} / \mathrm{L}$ & 27.4 & 25.8 & 10122 & 33.3 & 16.2 & 1567 \\
ALT & $\mathrm{U} / \mathrm{L}$ & 18.4 & 15.6 & 7101 & 11.6 & 3 & 1015 \\
Phosphorus & $\mathrm{mg} / \mathrm{dL}$ & 4.79 & 2.8 & $2.2-11.98$ & 5.8 & 1.22 & $4.6-7.4$ \\
Calcium & $\mathrm{mg} / \mathrm{dL}$ & 12.34 & 1.48 & $9.11-14.8$ & 11.48 & 1.32 & $10.2-13.7$ \\
Albumin & $\mathrm{g} / \mathrm{dL}$ & 2.65 & 0.35 & $2.2-3.5$ & 2.89 & 0.34 & $2.6-3.2$ \\
\hline
\end{tabular}

Table 4 Values of the Hemoleucogram of the Group of male youth and adult

\begin{tabular}{|c|c|c|c|c|c|c|c|}
\hline \multirow[b]{2}{*}{ Parameters } & \multirow[b]{2}{*}{ Unit } & \multicolumn{3}{|c|}{ Adult Males } & \multicolumn{3}{|c|}{ Juvenile Males } \\
\hline & & Average & SD & Range & Average & SD & Range \\
\hline Hematocrit & $\%$ & 24.31 & 3.87 & 1831 & 23.43 & 2.86 & 2026 \\
\hline Hemoglobin & $\mathrm{g} / \mathrm{dL}$ & 8.12 & $1.4 \mathrm{I}$ & 69.7 & 7.74 & 0.87 & $6.7-8.8$ \\
\hline Red Blood Cells & $\left(10^{\wedge} \mid 2 / I\right)$ & 0.72 & 0.16 & $0.3-1.1$ & 0.7 & 0.11 & $0.5-0.9$ \\
\hline Mcv & $\mathrm{FI}$ & 346,3 & 68.5 & 245472 & 341,7 & 79.9 & 266500 \\
\hline Mch & $\mathrm{Pg}$ & 116,4 & 2.34 & 78190.3 & 117,2 & 1.48 & 83134 \\
\hline Mchc & $\mathrm{g} / \mathrm{dL}$ & 32.72 & 3.5 & $28.3-45.5$ & 32.79 & 2.2 & $30.4-35.4$ \\
\hline White Blood Cells & $\left(10^{\wedge} 9 / /\right)$ & 9 & 4.54 & $3.3-22.6$ & 9.67 & 5.72 & $5.2-17.1$ \\
\hline Heterophile & $\%$ & 21 & 10.5 & 448 & 15 & 6.63 & 428 \\
\hline Heterophile absolute & $\left(10^{\wedge} 9 / 1\right)$ & 1.97 & 1.64 & $0.2-8.8$ & 1.36 & 0.92 & $1.3-3.6$ \\
\hline Eosinophils & $\%$ & 1.25 & 1.91 & $0-9$ & 1.72 & 3.22 & $0-11$ \\
\hline Eosinophils Absolute & $\left(10^{\wedge} 9 / 1\right)$ & 0.12 & 0.26 & $0-1.1$ & 0.16 & 0.33 & $0-1$ \\
\hline Lymphocytes & $\%$ & 44.25 & 18.3 & 1286 & 53,16 & 16.1 & 3889 \\
\hline Lymphocytes Absolute & $\left(10^{\wedge} 9 / /\right)$ & 3.73 & 1.95 & $0.6-9$ & 5.56 & 5.25 & 110 \\
\hline Monocytes & $\%$ & 1.12 & 1.25 & $0-4$ & 1.5 & 1.5 & $0-4$ \\
\hline Monocytes Absolute & $\left(10^{\wedge} 9 / 1\right)$ & 0.1 & 0.16 & $0-0.7$ & 0.12 & 0.11 & $0.1-0.11$ \\
\hline Azurophils & $\%$ & 28.1 & 12.3 & 355 & 23.5 & 8.4 & 640 \\
\hline Azurophils Absolute & $\left(10^{\wedge} 9 / 1\right)$ & 2.63 & 1.88 & $0-7$ & 2 & 0.99 & $1.3-4.1$ \\
\hline Basophils & $\%$ & 4.38 & 6 & $0-40$ & 4.25 & 3.1 & $0-8$ \\
\hline Basophils Absolute & $(10 \wedge 9 / 1)$ & 0.38 & 0.55 & $0-2.6$ & 0.38 & $0.4 I$ & $0.1-1$ \\
\hline Thrombocytes & $\left(10^{\wedge} 9 / 1\right)$ & 13.7 & 5.49 & $5.6-24$ & 16.3 & 1.74 & 1416 \\
\hline
\end{tabular}

Heterophils $\left(10^{\wedge} 9 / 1\right)$ with average value for adult females of $2.6 \pm 1.7$, for juvenile females $1 \pm 0$, 5 , for adult males $1.97 \pm 1.6$ and juvenile males $1.36 \pm 0.92$ (Figure 2) with $\mathrm{P}$ value $=0.002$ indicates that there are significant differences between adult females with young females $(\mathrm{Pv}=0.006)$ and adult females with young males $(\mathrm{P}=0.031)$ however among other groups no statistically significant difference was observed lymphocytes $\left(10^{\wedge} 9 / 1\right)$ with value average for adult females of $3.6 \pm 2.6$, for juvenile females $4.9 \pm 2.7$, for adult males $3.73 \pm 1.95$ and juvenile males $5.56 \pm 5.25$ (Figure 2) with $\mathrm{Pv}=$ 0.004 showed that there is significant difference between the Group of adult females with young females $(\mathrm{Pv}=0.006)$ and adult females with young males $(\mathrm{P}$ value $=0,049)$ being higher averages is the juvenile individuals (Figure 2). For other hematological parameters were not evident statistically significant differences between groups (Table 2 $\& 4$ ). Similar for serum chemistry parameters (Table $3 \& 5$ ) were not evident not statistically significant differences between groups. 
Table 5 Values of blood chemistry of the Male adult and juvenile groups

\begin{tabular}{llllllll}
\hline & \multicolumn{3}{c}{ Adult males } & \multicolumn{5}{l}{ Juvenile males } \\
\cline { 3 - 8 } Parameters & Unit & Average & Sd & Range & Average & Sd & Range \\
\hline Glucose & $\mathrm{mg} / \mathrm{dL}$ & 50,46 & 30.5 & $17 \mathrm{I} 84$ & 50.7 & 28.8 & 40102 \\
Proteins & $\mathrm{g} / \mathrm{dL}$ & 6.27 & 1.12 & 710 & 6.33 & 1.04 & 57.8 \\
Urea & $\mathrm{mg} / \mathrm{dL}$ & 3.75 & 2.47 & $0.7-12.7$ & 2.4 & 0.74 & 13.3 \\
Uric Acid & $\mathrm{mg} / \mathrm{dL}$ & 5.54 & 3.58 & $1.13-9.8$ & 5.38 & 3.82 & $2.4-13.6$ \\
AST & $\mathrm{U} / \mathrm{L}$ & 34.92 & 30.9 & 7180 & 30,25 & 27.5 & 768 \\
ALT & $\mathrm{U} / \mathrm{L}$ & 16 & 9.48 & 540 & 10.2 & 4.5 & 215 \\
Phosphorus & $\mathrm{mg} / \mathrm{dL}$ & 4.48 & 1.83 & $1.7-7.4$ & 3.88 & 0.85 & $2.1-5.2$ \\
Calcium & $\mathrm{mg} / \mathrm{dL}$ & 12.29 & 1.9 & $6.5-16.1$ & 12.9 & 1.33 & $1 \mathrm{I} .1-14$ \\
Albumin & $\mathrm{g} / \mathrm{dL}$ & 3 & 0.55 & $1.8-4.33$ & 3.03 & $0.5 \mathrm{I}$ & $2.4 \mathrm{I}-3.7$ \\
\hline
\end{tabular}

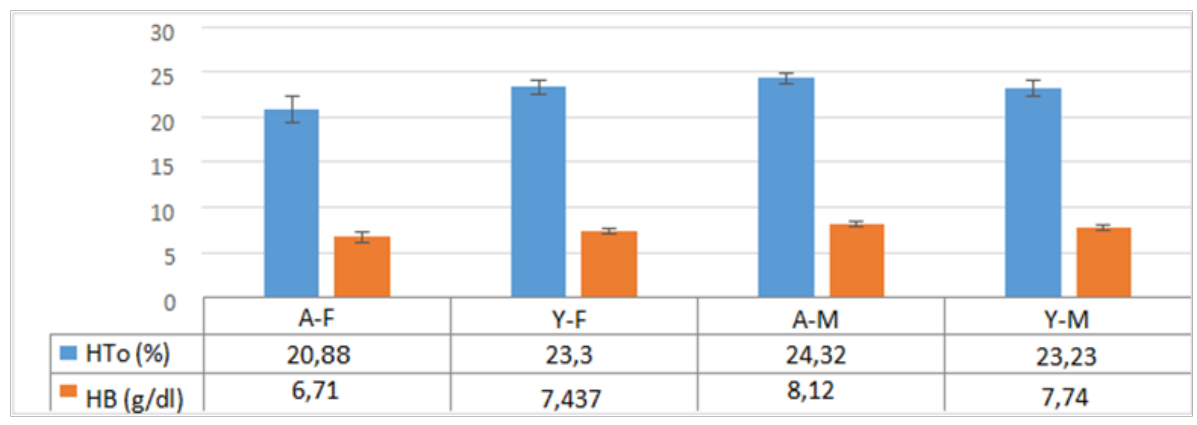

Figure I Represents the averages of the values of hematocrit (HTo. \%) and hemoglobin (HB. g/dl) of the sample groups.

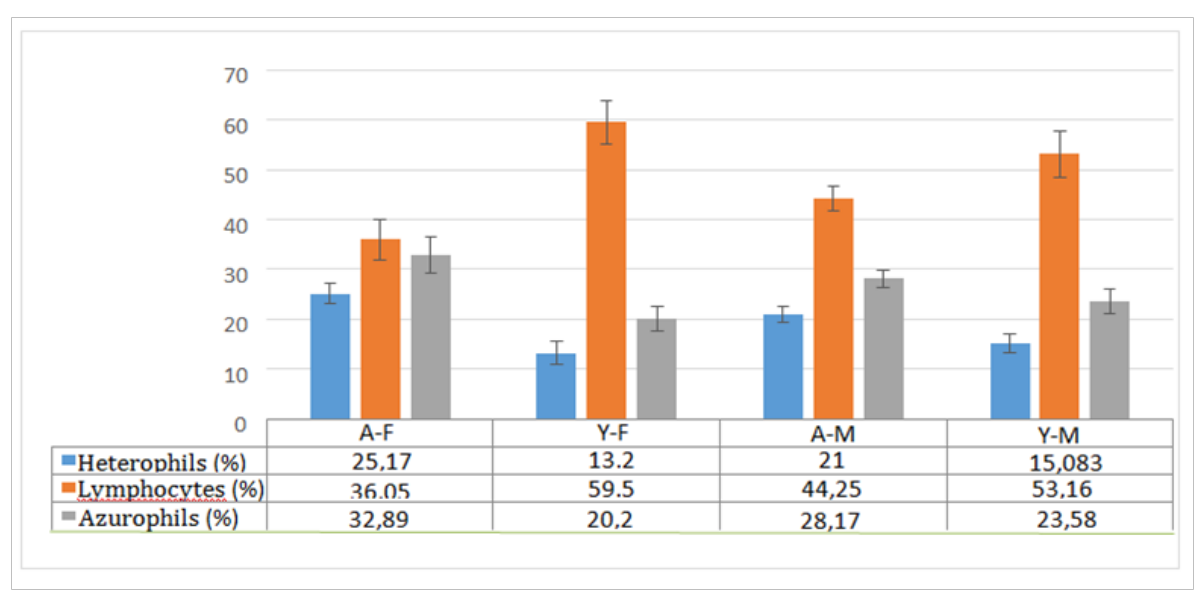

Figure 2 Represents the averages of the values of Heterophile (\%), lymphocytes (\%) and Azurophils (\%) of the sample groups.

\section{Discussion}

The type of management, environment and diseases, in general, are related to the hemogram alterations in all animal species, a Hemoleucogram of snakes of the same species but at different ambient conditions is being studied to characterize the State of health of the populations of snakes. ${ }^{3}$ For which the term health is to be interpreted not as the absence of disease but as the condition of general well-being and success of life. ${ }^{4}$ Since the Hematology and plasma biochemistry of snakes may vary depending on various physiological and external factors such as: sex, age, pregnancy, stress, climate, altitude and captivity, it is important to consider these factors when establishing ranges of reference. ${ }^{4}$ To take into account this values is important to observe the possible differences in the results of the blood of animals in captive versus wild animals where the variations can be attributed to the presence of ectoparasites, hemoparasites. A high count of red blood cells and a count low of heterophile are reported in cobra King in captivity compared with cobras King wild. ${ }^{5}$ 
As a first approach to the discussion, the values of the hematocrit (HTo \%) of the subjects of this study, there were no significant differences between groups with a higher $\mathrm{p}$ value $<0,05$ (Figure 1) (Table $2 \& 4$ ), the values below the minimum of the range established $(24-40 \%)$ in the literature ${ }^{6,7}$ however averages are closer to the stated values $(22.5 \%)$ by (Fowler \& Miller 2015). The value of hemoglobin ( $P$ value $=0,057)$ indicates differences between the male adult group and other groups. None of the groups found a marked change with reference to the literature being among the ranks 3, 3-15, $3 \mathrm{~g} / \mathrm{dl} .{ }^{8,9} \mathrm{As}$ for the $\mathrm{MCV}$, the $\mathrm{MCH}$ and the $\mathrm{MCHC}$, there were marked changes in comparison with the values set in the literature. ${ }^{6,9}$

Heterophile differences between groups are explained that age can be a factor that directly affects the process of hematopoietic in mammals and possibly in reptiles. ${ }^{10}$ The values of the study lies within the range established in the literature. ${ }^{9,11}$ For the parameter lymphocytes (\%) the given differences in terms of the variable age are contrary to reports obtained by Troiano ${ }^{12}$ in which a study was conducted at snakes of the species Crotatuls durissus terrificus where there were no variations in haematological parameters in sex and age. The hematological parameters; eosinophils, monocytes, Azurophils, basophils and platelets of different Boa constrictor groups included in the study did not show any significant variation with regard to age or sex, results also found in the study ${ }^{12}$ however the ranges derived from monocytes and eosinophils on average are higher than the reported in the literature. ${ }^{11,13}$ With respect to the blood chemistry values for glucose, total protein and albumin in blood obtained in the study were not significantly different between groups of males and females and adults and juveniles. Results consistent with that found by Dennis Jose da silva ${ }^{14}$ at Boas, where there was influence in these values of blood chemistry by the age and sex variables. However, concentrations are within the ranges established in the literature. ${ }^{15,16}$ On the other hand the values of urea and uric acid showed no significant difference, also reported by Gomez 4 in the species snakes Crotalus simus that no relationship was found between longevity and sex on the values of uric acid and Kalena Barros ${ }^{13}$ study on Boa constrictor that was not influenced levels of urea by sexual factors Similarly the values of urea and uric acid are between the ranges reported in Boa constrictor. ${ }^{6}$ The data obtained in this study of ALT and AST did not show differences by sex and age $(P$ value $=0,317$ and $P$ value $=0,451)$ results respectively, also given by Dennis Jose da silva ${ }^{14}$ in which there was no variations in the concentrations of these enzymes evaluating the same variables. The AST of the four groups values were found to be increased with respect to the data reported by (Chodini, 1982) however were found within the range established by Mader. ${ }^{6}$ All groups' ALT values were found within the established values Carpenter. ${ }^{11}$ For his part in the plasma concentrations of calcium there was no differences between groups of the same result reported by Dennis Jose da silva ${ }^{14}$ who did not observe significant differences in calcium concentrations by age or sex. Even more the values of this study are consistent with those reported by Mader ${ }^{6}$ and Martinez-silvestre, et al. ${ }^{17}$ and Cuenca. ${ }^{13}$ The values of phosphorus is slightly increased in comparison with the data. ${ }^{6,14}$

\section{Conclusion}

In conclusion we have shown that there is a statistically significant difference between age and haematological parameters of heterophils which can be found in greater numbers in adults than in young individuals, lymphocytes can see fewer in adult individuals that in young individuals and according with the sex, the hemoglobin values are greater in males than in females. The present study aims to be a guideline for future research in the area of haematology and biochemistry in snakes, especially in the species Boa constrictor, thus contributing to the improvement in the conservation and management of these specimens in each of the center of attention and assessment of wildlife that work with this species and also in use as a base but keep in mind the variation presented the data in this type of study, because the wildlife that entering to the center are wild species under high levels of stress and many others in precarious health conditions.

\section{Acknowledgements}

None.

\section{Conflict of interest}

Author declares that there is no conflict of interest.

\section{References}

1. Meyer Harvey. Veterinary Laboratory Medicine: Interpretation and Diagnosis. $2^{\text {nd }}$ edition. London: Saunders; 2004. 365 p.

2. Troiano JC. Hematology in reptiles. Reptilia magazine specializing in reptiles, amphibians and arthropods. 2005;(51):79-82.

3. Ruben AGS. Comparative study of the values of hematological of snakes of cascaval (Crotalus durissus terrificus) free-living and captive. Biotemas. 2014:109-115.

4. Aaron Gomez. Hematología y bioquímica plasmática of the serpiente crotalus simus (serpentes: viperidae), in condictions of cautiverio. 2015.

5. Stacy NI, Alleman AR, Sayler KA. Diagnostic hematology of reptiles. Clin Lab Med. 2011;31(1):87-108.

6. Mader. Clinical Pathology of reptiles, in reptile Medicine and surgery. Missouri: Saunders; 2016.

7. Garcia A. Hematological parameters and differentiation of blood cells in Boa constrictor of the eco-archaeological Park Xcaret. Mexico: Universidad de Veracruz; 2015.

8. Fowler ME, Miller RE. Zoo and Wild Animal Medicine. Missouri: St Louis; 2014.

9. Anna M, Weiser GWR, Campbell TW. Veterinary hematology and clinical chemistry. Amesm Iowa: John wiley \& Sons; 2012

10. Novoa F, Tumay B. Surmericana hematologic findings (Iguana iguana), patients located in urban and suburban area of villavicencio (Meta). Orinoquia. 2008:67-79.

11. Carpenter JW. Exotic Animal Formulary. St Louis Missouri: Saunders 2005 .

12. Troiano JC. Haematological Reference Intervals of the south American Rattlesnake in captivity. Comparative Haematology International. 1997;7(2):109-112.

13. Martinez Silvestre A, Lavin Cuenca R. Hematology and blood cytology in reptiles. Clin Vet Peq Anim. 2011;31(3):131-141.

14. Dennis Jose da silva VC. Influence of sexo na biochemistry serica jiboas (Boa constrictor) Amazon to Brazil. Veterinary science. 2012:536-538.

15. Chodini RJ. Blood chemistry values of the common boa constrictors. American Journal of Veterinary Research. 1982;43(9):1701-1702.

16. Kalena Barros DC. Jibóia (Boa constrictor) biochemical values. Brazil Journal of Veterinary Research and Animal science. 2013:497-498.

17. Martinez Silvestre A, Lavin S, Cuenca R. The blood chemistry in clinic of reptiles. Difus Vet. 2013:31-40. 